\title{
МЕХАНІЗМИ БЮДЖЕТУВАННЯ ДІЯЛЬНОСТІ ПІДПРИЕМСТВА : МОЖЛИВОСТІ УПРАВЛІННЯ ФІНАНСОВОЮ БЕЗПЕКОЮ
}

\author{
DOI: $10.32620 /$ cher.2019.3.03
}

Постановка проблеми. У статті приводиться авторське думка щодо можливостей використання механізмів бюджетування діяльності підприємства у якості інструментів управління фінансовою безпекою. Лібералізація фінансових відносин і вільний транскордонний рух капіталу призвели до активізації внутрішніх і посилення дії зовнішніх шоків на розвиток економічних суб'єктів. Метою статті є дослідження теоретичних аспектів системи бюджетування як ін-струмента управлінням фінансовою безпекою підприємства, з метою формування цілісного уявлення про бюджетування як економічної категорії. Об'єктом дослідження виступає - процес бюджетування діяльності підприємства, його організаційноекономічні можливості та інструменти управління фінансовою безпекою підприємства. Mетоди, використані в дослідженні: системний підхід, метод узагальнення, порівняння, логічно-змістовний метод, монографічний метод, методи індукції та дідукції тощо. Основною гіпотезою є те, фінансова стійкість функціонуючого підприємства залежить від варіанту економічної політики, яка формується за рахунок структури інструментів бюджетування на підприємстві. Виклад основного матеріалу. Виявлено мотиви використання даного інструменту на підприємстві. Наведено ефективність використання бюджетування в управлінні фінансовою безпекою підприємства. Бюджетування дозволяє підвищити фінансову обгрунтованість управлінських рішень та ефективність інформаційного забезпечення управління підприємством; розме-жувати відповідальність між керівниками рі-зних рівнів організаційної ієрархії за результати і здійснити позитивний вплив на їх мо-тивацію; узгодити різні напрямки діяльності підрозділів та роботу підприємства загалом на основі єдиного скоординованого бюджету; вдосконалювати поточні бюджети через формування відповідності між плановими і фак-тичними показниками та результатами; передбачати обсяги матеріальних та фінансових потоків, структуру витрат. Оригінальність та практичне значення дослідження. В основі механізму забезпечення фінансової безпеки підприємства знаходиться системне поєднання певних інструментів, методів, важелів та інформаційно-аналітичного забезпечення, створюваних на базі принципів забез-печення фінансової безпеки, що об'єктивноіснують як економічні закономірності, а також виробляються суб'єктами управління фінансової безпеки підприємства для досягнення i захисту фінансових інте-ресів останнього. Висновки дослідження. Впровадження системі бюджетування суб'єкта господарювання уможливлює планування фінансово-господарської діяльності з розрахунком на досягнення конкретного фінансового результату та цільових фінансових показників. Таким чином, бюджетування являє собою ефективний інструмент управління фінансовою безпекою підприємства та виступає одним з основних процесів у системі фінансового планування.

Ключові слова:

бюджетування, інструмент, фінансова безпека підприємства, планування, стратегія.

\section{BUDGETING MECHANISMS OF ENTERPRISE ACTIVITY: FINANCIAL SECURITY MANAGEMENT OPPORTUNITIES}

Formulation of the problem. The article presents the author's opinion on the possibilities of using the mechanisms of budgeting the activity of the enterprise as tools of financial security management. The liberalization of financial relations and the free cross-border movement of capital led to the intensification of

1 Ліхоносова Ганна Сергіївна, д-р екон. наук, професор кафедри «Фінанси», Національний аерокосмічний університет ім. М. С. Жуковського «Харківський авіаційний інститут», м. Харків, Україна.

Likhonosova Ganna, Doctor of Economic Sciences, Professor of Finance Department National Aerospace University «Kharkiv Aviation Institute», Kharkiv, Ukraine.

ORCID ID: 0000-0001-6552-8920

e-mail: a.likhonosova@gmail.com

${ }^{2}$ Нецвітасва Олена Ігорівна, магістрант спеціальності «Фінанси, банківська справа та страхування», Національний аерокосмічний університет ім. М. Є. Жуковського «Харківський авіаційний інститут», м. Харків, Україна.

Netsvitaieva Olena, Master's degree of Finance, Banking and Insurance Specialty National Aerospace University «Kharkiv Aviation Institute», Kharkiv, Ukraine.

ORCID ID: 0000-0003-4406-165X

e-mail: lenanecvetaeva1997@gmail.com 
internal and external shocks on the development of economic entities. The purpose of the article is to study the theoretical aspects of the budgeting system as a tool for managing the financial security of an enterprise, in order to form a holistic view of budgeting as an economic category. The object of the study is the process of budgeting the activity of the enterprise, its organizational and economic capabilities and tools for managing the financial security of the enterprise. Methods used of the research: systematic approach, method of generalization, comparison, logical-meaningful method, monographic method, methods of induction and deduction, etc. The main hypothesis is that the financial stability of a functioning enterprise depends on the economic policy option, which is formed by the structure of the budgeting instruments of the enterprise. Presenting main material. The reasons for using this tool at the enterprise are revealed. The efficiency of the use of budgeting in the management of financial security of the enterprise is shown. Budgeting makes it possible to increase the financial soundness of management decisions and the effectiveness of information support of enterprise management; to differentiate between the leaders of different levels of the organizational hierarchy for results and to make a positive impact on their motivation; to agree on the different lines of activity of the units and the work of the enterprise as a whole on the basis of a single coordinated budget; improve current budgets by matching planned and actual indicators with results; to predict volumes of material and financial flows, cost structure. The originality and practical significance of the research. The basis of the mechanism of ensuring the financial security of the enterprise is a systematic combination of certain tools, methods, levers and information and analytical support, created on the basis of the principles of financial security, which objectively exist as economic laws, as well as produced by entities of financial security management of the enterprise to achieve and protecting the latter's financial interests. Conclusions of the research. The introduction of the entity's budgeting system enables the planning of financial and economic activities with the expectation of achieving a specific financial result and financial targets. Thus, budgeting is an effective tool for managing the financial security of an enterprise and acts as one of the main processes in the financial planning system.

Key words :

budgeting, tool, financial security of the enterprise, planning, strategy.

\section{МЕХАНИЗМЫ БЮДЖЕТИРОВАНИЯ ДЕЯТЕЛЬНОСТИ ПРЕДПРИЯТИЯ: ВОЗМОЖНОСТИ УПРАВЛЕНИЯ ФИНАНСОВОЙ БЕЗОПАСНОСТЬЮ}

Постановка проблемы. В статье приводится авторское мнение о возможностях использования механизмов бюджетирования деятельности предприятия в качестве инструментов управления финансовой безопасностью. Либерализация финансовых отношений и свободный трансграничное движение капитала привели к активизации внутренних и усиление действия внешних шоков на развитие экономических субъектов. Целью статьи является исследование теоретических аспектов системы бюджетирования как инструмента управлением финансовой безопасностью предприятия, с целью формирования целостного представления о бюджетировании как экономической категории. Объектом исследования выступает процесс бюджетирования деятельности предприятия, его организационно-экономические возможности и инструменты управления финансовой безопасностью предприятия. Методы, использованные в исследовании: системный подход, метод обобщения, сравнения, логически-содержательный метод, монографический метод, методы индукции и дидукции тому подобное. Основной гипотезой является то, финансовая устойчивость функционирующего предприятия зависит от варианта экономической политики, которая формируется за считается-нок структуры инструментов бюджетирования на предприятии. Изложение основного материала. Выявлено мотивы использования данного инструмента на предприятии. Приведены эффективность использования бюджетирования в управлении финансовой безопасностью предприятия. Бюджетирование позволяет повысить финансовую обоснованность управленческих решений и эффективность информационного обеспечения управления предприятием; разграничить ответственность между руками ре-них уровней организационной иерархии за результаты и осуществить положительное влияние на их мотивацию; согласовать различные направления деятельности подразделений и работу предприятия в целом на основе единого скоординированного бюджета; совершенствовать текущие бюджеты через формирование соответствия между плановыми и фактическими показателями и результатами; предусматривать объемы материальных и финансовых потоков, структуру затрат. Оригинальность и практическое значение исследования. В основе механизма обеспечения финансовой безопасности предприятия находится системное сочетание определенных инструментов, методов, рычагов и информационно-аналитического обеспечения, создаваемых на базе принципов обеспечения финансовой безопасности, объективно существуют как экономические закономерности, а также производятся субъектами управления экономической безопасности предприятия для достижения и 
защиты финансовых инте-сов последнего. Выводы исследования. Внедрение системе бюджетирования предприятия позволяет планирования финансово-хозяйственной деятельности с расчетом на достижение конкретного финансового результата и целевых финансовых показателей. Таким образом, бюджетирование представляет собой эффективный инструмент управления финансовой безопасностью предприятия и выступает одним из основных процессов в системе финансового планирования.

\section{Ключевые слова:}

бюджетирования, инструмент, финансовая безопасность предприятия, планирование, стратегия.

Постановка проблеми. В умовах економічної нестабільності, скорочення вільних фінансових ресурсів, підвищення їхньої вартості та зниження доступності для підприємств нині гостро постає питання щодо використання якісних управлінських технологій, серед яких одне 3 провідних місць посідає фінансове планування та бюджетування.

Трансформаційні процеси у світовій та українській економіці суттєво змінили умови реалізації державного менеджменту, особливості проведення господарсько-фінансової діяльності підприємств і специфіку функціонування фінансового ринку. Лібералізація фінансових відносин і вільний транскордонний рух капіталу призвели до активізації внутрішніх і посилення дії зовнішніх шоків на розвиток економічних суб'єктів. Перед державними органами влади постали проблеми збереження національних інтересів і підтримки добробуту господарюючих суб'єктів за рахунок проведення виваженої бюджетноподаткової, грошово-кредитної, інвестиційної та інших політик у період фінансової нестабільності. Суб'єкти господарювання намагаються протистояти деструктивним чинникам за рахунок проведення ефективної антикризової політики. Фінансовий ринок і ринок фінансових послуг як джерело акумуляції сучасних кризових явищ, що поширюються надалі на всі сфери економіки, взагалі вимагають формування нових інструментів забезпечення їх фінансової безпеки $[1$, с. 6].

Впровадження бюджетування в діяльності вітчизняних суб'єктів господарювання забезпечує залучення всіх резервів підвищення ефективності функціонування підприємств для виробництва конкурентоспроможної продукції на основі цільової орієнтації та координації роботи всіх структурних підрозділів. Саме бюджетування сприяє формуванню якісної системи планування та управління оборотними активами, капіталом та іншими ресурсами, підвищенню ефективності їх розподілу та використання.
Аналіз останніх досліджень i публікацій. Вагомий внесок у дослідження процессу бюджетування на підприємствах у своїх працях зробили зарубіжні вчені: I. Ансофф, Р. С. Каплан, О. І. Лаврушин, Е. Майер, М. Мескон, Г. П. Панова, Ч. Т. Хорнгрен та інші. Але вітчизняні умови функціонування суб'єктів господарювання вимагають адап тації та перегляду західних досліджень до особливостей національної економіки. У вітчизняній літературі проблеми бюджетування вивчали А. Г. Загородній, М. С. Пушкар, І.О. Бланк, М. Д. Білик, С. В. Онищенко, Г. Г. Кірейцев, О. С. Стоянова, Л. В. Нападовська, М. Г. Чумаченко, А. Д. Шеремет та інші. Авторські напрацювання представлені дослідженнями щодо організаційних засад обліку та аудиту фінансових результатів підприємств [1, с. 144-148], та можливостями каталізаційного розвитку підприємництва саме через аспект зміни інструментів фінансування [3, с. 7-17].

Бюджетування $є$ складною системою управління сучасним підприємством, тому впровадження його елементів у практику вітчизняних суб'єктів господарювання розглядається як тривалий процес, що охоплює широке коло організаційних, інформаційнотехнічних та методичних питань, які потребують подальшого аналізу, вивчення та деталізації.

Метою статті $\epsilon$ дослідження теоретичних аспектів системи бюджетування як інструмента управлінням фінансовою безпекою підприємства, 3 метою формування цілісного уявлення про бюджетування як економічної категорії.

Виклад основного матеріалу дослідження. Впровадження механізму бюджетування на вітчизняних підприємствах $є$ необхідним кроком для досягнення успішного функціонування, підвищення фінансової безпеки підприємства, забезпечення цільового використання та економії ресурсів, прийняття обгрунтованих управлінських рішень, спря- 
мування діяльності під- розділів підприємства на оптимізацію надходжень та видатків.

До визначення терміна «бюджетування» автори наукових праць підходять порізному. Так, у працях одних науковців бюджетування розглядається як процес. Наприклад, у роботі Р. С. Квасницької [4, с. 54-56] відзначено, що бюджетування - це «безперервний процес складання і коригування бюджетів підприємства на основі взаємопов'язаних прогнозних розрахунків, які визначають надходження i видатки, доходи i витрати, прибутки і збитки, а також контролю та оцінки виконання бюджетів, що сприяє ефективному управлінню фінансовими ресурсами та узгоджує між собою основні складові діяльності підприємства - фінанси, постачання, виробництво, збут 3 метою досягнення певних фінансових результатів».

Інші науковці визначають бюджетування як інструмент управління або управлінську технологію. Так, В. М. Федосова [5, с. 3-23] визначає бюджетування як управлінську технологію, основу фінансової дисципліни, яка використовується для підвищення відповідальності керівників різного рівня управління за фінансові результати, які досягаються очолюваними ними структурними підрозділами.

Більшість науковців ототожнюють бюджетування і планування. Б. Колосок засвідчує, що «бюджетування - це планування діяльності підприємства через розробку системи пов'язаних між собою бюджетів, які комплексно орієнтовані на ринкові потреби й покликані забезпечувати стійкий фінансовий стан і поступовий розвиток підприємства відповідно до його головної мети та статутних документів» [6].

Зважаючи на вищезазначене, можна зробити висновок про те, що частина авторів дають узагальнююче визначення і вважають бюджетування [7, с. 22-26] універсальним інструментом управління, інші дослідники відносять бюджетування більше до фінансової сфери (фінансового менеджменту), треті акцентують увагу саме на прогнозуванні та плануванні.

Визначимо складові механізму забезпечення фінансової безпеки підприємства. Зважаючи на те, що фінансова безпека є підсистемою фінансового механізму підприємства, механізм іiі забезпечення повинен формуватися через призму останнього, тобто через систему управління фінансовими відносина- ми шляхом використання певних принципів, фінансових важелів, інструментів, фінансових методів, правового й інформаційного забезпечення, за допомогою фінансових досліджень, які дозволяють досягти основні цілі підприємства [8, с.128].

Основні елементи (складові) механізму забезпечення фінансової безпеки підприємства повинні формуватися зважаючи на фінансові інтереси підприємства: зростання ринкової вартості підприємства, максимізація прибутку, достатність основного і оборотного капіталу, наявність необхідного обсягу інвестиційних ресурсів, оптимізація відрахувань до бюджету.

Окрім того, враховувати принципи управління фінансовою безпекою підприємства: первинність господарського законодавства; застосування програмно-цільового управління; обов'язкове визначення сукупності власних фінансових інтересів підприємства у складі його місії; інтегрованість підсистеми управління фінансовою безпекою підприємства із загальною системою фінансового менеджменту; забезпечення збалансованості фінансових інтересів підприємства, окремих його підрозділів і персоналу; взаємна матеріальна відповідальність персоналу і керівництва за стан фінансової безпеки підприємства необхідність постійного моніторингу реальних і потенційних загроз; відповідність заходів щодо забезпечення фінансової безпеки економічній стратегії розвитку підприємства, його місії; координація реалізації заходів щодо забезпечення фінансової безпеки на підприємстві; необхідність і своєчасність удосконалення в разі потреби системи фінансової безпеки підприємства; наявність зворотного зв'язку; необхідність організаційного і методичного оформлення підсистеми фінансової безпеки; мінімізація витрат на забезпечення фінансової безпеки підприємства.

Отже, бюджетування на підприємстві один із важливих елементів ресурсного забезпечення управлінського обліку, управлінська технологія, що підпорядкована вимогам фінансової стратегії, включає в себе систему взаємопов'язаних бюджетів та базується на розробці, контролі виконання та аналізі відхилень бюджетних показників від фактичних за центрами фінансової відповідальності 3 метою досягнення короткострокових та довгострокових цілей для підвищення ринкової вартості підприємства. 
Бюджетування дозволяє не тільки планувати й оперативно контролювати потоки фінансових ресурсів, але й визначати причини відхилень та моделювати наслідки різних управлінських рішень. Бюджетування сприяє прийняттю правильних управлінських рішень, допомагає здійснити контроль та управління матеріальними, фінансовими та грошовими ресурсами, що забезпечує підвищення фінансової безпеки підприємства.

Аналіз літературних джерел дозволив встановити, що об'єктом бюджетування є процес планування фінансових ресурсів та грошових потоків суб'єкта господарювання, а предметом - бюджетні показники і характеристики підприємства, що необхідні для планування фінансових ресурсів і грошових потоків.

Суб’єктами бюджетування виступають функціональні служби та підрозділи підприємства, тобто всі елементи фінансової структури, що формують бюджети цих підрозділів та єдиний консолідований бюджет.

Функції бюджетування наведені $\mathrm{y}$ табл.1.

Т а б ли ц я 1

\section{Функції бюджетування діяльності підприсмства}

\begin{tabular}{|l|l|}
\hline \multicolumn{1}{|c|}{ Функція } & \multicolumn{1}{|c|}{ Сутність щодо впровадженні на підприємстві } \\
\hline планування & $\begin{array}{l}\text { функція бюджетування, що проявляється в забезпеченні планування фінансово- } \\
\text { господарської діяльності підприємства та його структурних підрозділів шляхом } \\
\text { розробки фінансових планів, створенні схеми взаємодії бюджетів }\end{array}$ \\
\hline прогнозування & $\begin{array}{l}\text { розрахунок та обгрунтування прогнозних показників щодо виконання планових } \\
\text { завдань на основі даних фінансового та бухгалтерського обліку; }\end{array}$ \\
\hline мотивація & $\begin{array}{l}\text { формування мотивів поведінки для виконання бюджетних показників, як крите- } \\
\text { ріїв ефективності діяльності як окремих підрозділів, так і підприємства загалом; }\end{array}$ \\
\hline контроль & $\begin{array}{l}\text { своєчасний контроль за досягенням планових цілей шляхом зіставлення фак- } \\
\text { тичних та запланованих результатів. }\end{array}$ \\
\hline координація & взаємодія та узгодження діяльності всіх структурних підрозділів підприємства; \\
\hline аналіз & $\begin{array}{l}\text { аналіз планових і фактичних даних, порівняння планів та результатів, оцінка } \\
\text { відхилень та їх причин, виявлення скритих резервів; }\end{array}$ \\
\hline
\end{tabular}
Джерело: розроблено авторами

Аналізуючи табл.1., можна сформувати мету бюджетування. Метою бюджетування $є$ підвищення економічної ефективності функціонування підприємства та його ринкової вартості шляхом покращення схеми взаємодії всіх його структурних підрозділів для вирішення поставлених завдань.

Основні завдання бюджетування витікають із його головної мети і можуть бути сформульовані таким чином (табл.2.).

Т а б ли ц я 2

\section{Завдання бюджетування для підвищення фінансової безпеки підприсмства}

забезпечення поточного планування фінансово-господарської діяльності підприємства на визначений період;

виявлення потреби в грошових та інших ресурсах, оптимізація фінансових потоків;

забезпечення координації, комунікації та кооперації структурних підрозділів та центрів фінансової відповідальності;

обгрунтування витрат підприємства, встановлення їх лімітів;

підвищення керованості підприємства та своєчасне виявлення вузьких місць в управлінні; оптимізація витрат і прибутку підприємства;

оцінка та контроль ефективності роботи підрозділів підприємства, аналіз причин, що викликали проблеми і відхилення та оперативне корегування значень.

\section{Джерело: розроблено авторами}

У сучасних умовах господарювання бюджет $є$ невід'ємною частиною планування, прогнозування та контролю основних показників діяльності підприємства, важливим ін- струментом бізнесу, інструментом управління фінансовою безпекою, обліку та контролю ресурсів і фінансових результатів. 
Бюджетування дозволяє підвищити фінансову обгрунтованість управлінських рішень та ефективність інформаційного забезпечення управління підприємством; розмежувати відповідальність між керівниками різних рівнів організаційної ієрархії за результати і здійснити позитивний вплив на їх мотивацію; узгодити різні напрямки діяльності підрозділів та роботу підприємства загалом на основі єдиного скоординованого бюджету; вдосконалювати поточні бюджети через формування відповідності між плановими і фактичними показниками та результатами; передбачати обсяги матеріальних та фінансових потоків, структуру витрат та ін. [9].

Переваги та недоліки впровадження інструменту бюджетування на підприємстві наведені у табл. 3.

Т а б ли ц я 3

Переваги та недоліки впровадження бюджетування на підприсмстві

\begin{tabular}{|l|l|}
\hline \multicolumn{1}{|c|}{ Переваги } & \multicolumn{1}{|c|}{ Недоліки впровадження } \\
\hline $\begin{array}{l}\text { інтеграція стратегічного та оперативного } \\
\text { планування }\end{array}$ & трудомісткість процесу бюджетування \\
\hline $\begin{array}{l}\text { збільшення якості та гнучкості управління } \\
\text { підприємством, підвищення відповідальності } \\
\text { за фінансові результати діяльності }\end{array}$ & $\begin{array}{l}\text { недостатня автоматизація системи } \\
\text { бюджетування }\end{array}$ \\
\hline $\begin{array}{l}\text { підвищення координації роботи підприєм- } \\
\text { ства в процесі формування та виконання } \\
\text { бюджетів загалом }\end{array}$ & $\begin{array}{l}\text { складність і висока вартість впровадження сис- } \\
\text { теми бюджетування }\end{array}$ \\
\hline $\begin{array}{l}\text { можливість оперативного контролю за } \\
\text { відхиленням фактичних показників від пла- } \\
\text { нових, виявлення їх причин }\end{array}$ & $\begin{array}{l}\text { невідповідність реальних цілей підприємства та } \\
\text { цілетування тощо }\end{array}$ \\
\hline
\end{tabular}

Джерело: розроблено авторами

У загальному вигляді можна виділити п'ять етапів впровадження системи бюджетування в організації. Мета першого етапу полягає в розробці моделі структури, що дозволяє встановити відповідальність за виконання бюджетів і контролювати джерела виникнення доходів і витрат. На другому етапі визначається основна логічна схема формування зведеного бюджету підприємства [10]. Під час здійснення третього етапу має бути сформована обліково-фінансова політика організації, тобто правила ведення й консолідації бухгалтерського, виробничого й оперативного обліку відповідно до обмежень, прийнятих при складанні та контролі (моніторингу) виконання бюджетів. Четвертий етап присвячений розробці регламенту планування, що визначає та закріплює процедури планування, моніторингу та аналізу причин невиконання бюджетів, а також поточного коригування бюджетів. П'ятий етап містить у собі роботи зі складання операційного та фінансового бюджетів на плановий період, проведення сценарного аналізу, коригування системи бюджетування за результатами аналізу іiі відповідності до потреб.

Висновки та перспективи подальших досліджень. Бюджетування підприємства за- безпечує ефективне функціонування та розвиток суб'єкта господарювання та відповідає вимогам оптимальності, гнучкості, результативності та системності. Воно допомагає прогнозувати зміну кон'юнктури ринку, отримувати конкурентні переваги через створення ефективної системи управління ресурсами, яка дозволяє передбачати можливі проблеми та відповідним чином планувати майбутні дії. Таким чином, в основі механізму забезпечення фінансової безпеки підприємства знаходиться системне поєднання певних інструментів, методів, важелів та інформаційно-аналітичного забезпечення, створюваних на базі принципів забезпечення фінансової безпеки, що об'єктивноіснують як економічні закономірності, а також виробляються суб'єктами управління фінансової безпеки підприємства для досягнення і захисту фінансових інтересів останнього.

Впровадження системі бюджетування суб'єкта господарювання уможливлює планування фінансово-господарської діяльності 3 розрахунком на досягнення конкретного фінансового результату та цільових фінансових показників. Таким чином, бюджетування являє собою ефективний інструмент управління фінансовою безпекою підприємства та 
виступає одним 3 основних процесів у системі фінансового планування.

\section{Література}

1. Управління фінансовою безпекою економічних суб'єктів : навч. посіб.; за заг. ред. С. М. Фролова ; [С. М. Фролов, О. В. Козьменко,А. О. Бойко та ін.]. - Суми : ДВНЗ "УАБС НБУ", 2015. - $332 \mathrm{c}$.

2. Ліхоносова Г. С. Організаційні засади обліку та аудиту фінансових результатів підприємств / Г. С. Ліхоносова, І. Р. Лазебна // Науковий вісник Ужгородського національний університету. Серія Міжнародні економічні відносини та світове господарство. - 2019. - Вип. 25. Ч. 1. - С. 144-148.

3. Ліхоносова Г. С. Фінансування каталізаційного розвитку підприємництва: європейський вектор / Г. С. Ліхоносова, О. В. Бєлов // Науковий погляд: економіка та управління. - 2019. - № 2(64). - С. 7-17.

4. Квасницька P. С. Бюджетування на підприємстві: суть та основні передумови ефективного застосування. / Р. С. Квасницька, С. О. Джерелейко // Вісник Хмельницького національного університету. Економічні науки. - 2018. - № 5, т. 1. - C. 54-56.

5. Федосова В. М. Сутність і проблематика бюджетування: українські реалії. / В. М. Федосова // Фінанси України. - 2018. - № 1. - С. $3-23$.

6. Колосок В. Бюджетування структурних підрозділів / В. Колосок // Схід. - 2017. - № 2 (116). - С. 29-35.

7. Кириченко $O . A$. Вдосконалення управління фінансовою безпекою підприємств в умовах фінансової кризи / О. А. Кириченко, І. В. Кудря // Інвестиції: практика та досвід. - 2009. - № 10. - С. 22-26.

8. Лаврова Ю. В. Механізм забезпечення фінансової безпеки підприємства / Ю. В. Лаврова // Вісник економіки транспорту і промисловості. - 2010. - № 29. - С. 127-130.

Стаття надійшла

до редакції : 01.09.2019 p.
9. Крайник О. П. Фінансовий менеджмент: навч. посіб. Київ: Дакор, 2017. - 260 с.

10. Пушкар М. С. Управлінський облік: навч. посіб. 2-ге вид., переробл. і доп. Тернопіль: Поліграфіст, 2016. - 160 с.

\section{References}

1. . Frolov, $M$ \& Kozmenko, O. V. \& Boyko, A. O. (Ed). (2015). Management of financial security of economic entities: training. Allowance. Sumy: DVBS "UABS NBU”, 332.

2. Likhonosova, G. S. \& Lazebna, I. R. (2019). Organizational basis for accounting and auditing of financial results of enterprises. Scientific Bulletin of Uzhgorod National University. International Economic Relations and World Economy Series, 25, 144-148.

3. Likhonosova, G. S. \& Beylov, O. V. (2019). Financing of the Catalyzing Development of Entrepreneurship: A European-Peoples Vector. Scientific view: economics and management, 2 (64), 7-17.

4. Kvasnytska, R. S. \& Dzhereleiko, S. O. (2018). Budgeting at the enterprise: the essence and basic prerequisites for effective application. Bulletin of Khmelnitsky National University. Economic Sciences, 5, Vol., 54-56.

5. Fedosova, V. M. (2018). The essence and problem-tics of budgeting: Ukrainian realities. Finance of Ukraine, 1, 3-23.

6. Kolosok, V. (2017). Budgeting of structural units. East, 2 (116), 29-35.

7. Kirichenko, O. A. \& Kudrya, I. V. (2009). Improving the management of financial security of enterprises in times of financial crisis. Investments: practice and experience, 10, 22-26.

8. Lavrova, $Y$. V. (2010). The mechanism of ensuring the financial security of the enterprise. Bulletin of the economy of transport and industry, 29, 127-130.

9. Krainik, A. P. (2017). Financial Management: Educ. tool. Kyiv: Dakor, 260.

10.Pushkar, M. S. (2016). Management accounting: teaching. tool. 2nd ed., Reworked. and ext. TerNopil: Polygraphist, 160.

Стаття прийнята

до друку: 27.09.2019 p.

\section{Бібліографічний опис для цитування :}

Ліхоносова Г. С. Механізми бюджетування діяльності підприємства : можливості управління фінансовою безпекою / Г. С. Ліхоносова, О. І. Нецвітаєва // Часопис економічних реформ. - 2019. № 3 (35). - C. 24-30. 